\title{
温暖化政策支援モデルのための 全球水資源影響関数の開発
}

\begin{abstract}
花崎直太 ${ }^{1}$, 増富祐司 ${ }^{2}$, 高橋粱 ${ }^{3}$, 肱岡靖明 4 , 原沢英夫 5 , 松岡譲 6
1 正会員 国立環境研究所 社会環境システム研究領域（广305-8506 茨城県つくば市小野川 16-2）

2 正会員 国立環境研究所 地球環境研究センター（テ305-8506 茨城県つくば市小野川 16-2）

3 正会員 国立環境研究所 地球環境研究センター（テ305-8506 茨城県つくば市小野川 16-2）

4 正会員 国立環境研究所 社会環境システム研究領域（テ305-8506 茨城県つくば市小野川16-2）

5 正会員 国立環境研究所 社会環境システム研究領域（テ305-8506 茨城県つくば市小野川16-2）

6 正会員 京都大学大学院 地球環境学堂(テテ615-8540 京都府京都市京都大学桂 Cクラスター)
\end{abstract}

\begin{abstract}
地球温暖化による気温と降水の変化に対して, 世界各国の水資源量がどのように応答するかを表す全球水資源 影響関数を作成した. まず詳細な全球水文モデルを利用し, 現在気候から気温を $-5^{\circ} \mathrm{C} か ら 15^{\circ} \mathrm{C}$ まで，降水量を $-75 \%$ から+200\%まで変化させた 252 通りのシミュレーションを行い, 各国の水資源量の応答をデータベース 化した. 利用時にはこのデータベースを参照するだけなので計算機負荷が小さく, 操作の度に気候条件が変化 する温暖化政策支援モデルへの搭載に向いている：このモデルから得られる国別の水資源量は元の詳細モデル から得られるものと約 $20 \%$ の誤差範囲で一致し，十分な代替性を示した.
\end{abstract}

Key Words: Global warming, Integrated assessment, Emission target, Water resources

1. はじめに

地球温暖化問題の解決には温室効果ガス排出の大幅な削 減が必要である. しかし, 排出量をいつまでに, どの程度 削減すべきか (大気中の安定化濃度と排出削減パス)につ いては，いまだに国際的合意が得られていない.これは将 来の社会・経済情勢や気候変化の見通しに不確実性が大き いことに加え，温暖化に関する膨大な科学的知見が集約さ れておらず, 政策担当者に十分活用されていないことが原 因となっている. そこで国立環境研究所と京都大学では温 暖化政策支援モデル AIM/Impact[Policy]の開発にとりく んできた 1.このモデルに目標とする安定化濃度を設定す ると, 経済影響が最小となる排出削減パスが瞬時に計算さ れ, 全球平均気温や海面上昇, 国別・分野別の影響力時系 列で示されるようになっている. 政策決定者は社会経済シ
ナリオや利用する気候モデル（GCM）を変化させて将来 の不確実性を考慮しながら, 設定した安定化濃度や排出削 減パスで経济や分野別の影響をどれくらい軽減できるの か, 簡単に評価することができる.

既存の温暖化影響評価は分野別の詳細なモデルを利用 したものが多いが; 計算機負荷が非常に高く，条件を様々 に変化させながら挙動を検討する政策支援モデルへの搭 載は現実的ではない. そこでAIM/Impact[Policy]では「影 響関数」と呼ばれる手法を利用して影響評価を行っている. これは, あらかじめ詳細モデルを利用して気象条件を変化 させた大量のシミュレーションを行い, 気温や降水といっ た気象要素の変化に対する影響量の応答をデータベース 化しておき, 利用時は計算中の気象条件に最も近いものを 読み取る仕組みである.

現時点でグローバルな農業の潜在生産性変化の影響関 
数のみが完成しているが2，温暖化は世界の水資源にも大

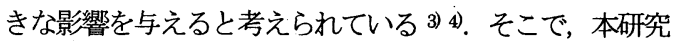
ではグローバルな水資源影響関数の作成を目的とする. そ のための方法は以下の通りである. まず詳細な全球水文モ デルを利用したシミュレーションを実施し，その結果が現 在の国別の水資源量を再現できることを確認する. 次に気 象条件を変化させた大量のシミュレーションを行い, 影響 関数を構筑する. このときのシミュレーションの妥当性も 詳細に検討する. 最後に影響関数から得られる国別の水資 源量と詳細モデルから得られるものとが一致することを 確認する. 水資源問題の本質は必要なときに必要な量の水 があるかという需要と供給の時間的・空間的バランスにあ るが, 本研究で㳊第一段階として, 平年の国別の年水資源 量のみを対象とする.

\section{2. 詳細モデルを利用した国別年水資源量}

\section{（1）現在の全球年流出量の計算}

全球水文モデルに全球気象データを与えることにより, 緯 度経度 $1^{\circ} \times 1^{\circ}$ の空間解像度で全球・平年の年流出量を推定 した. 全球水文モデルには花崎らの全球統合水資源モデル を利用した ${ }^{5}$.このモデルは緯度経度 $1^{\circ} \times 1^{\circ}$ の空間解像度, 日単位の時間解像度を持つ分布型の全球水文モデルであ る. このモデルは貯水池サブモデル, 取水サブモデルなど 複数のサブモデルからなるが, 本研究では陸面過程サブモ デルのみを利用する.このサブモデルは蔒発や積雪の詳細 な計算を行い，地表面の熱水収支を解くものであり，温暖 化時の気像条件の変化が水資源量に及ぼす影響を物理過 程に基づいて評価することができる6).

現実の河川では貯水池操作や取水が行われているので, 陸面過程サブモデル以外も結合したモデルを利用する方 が現害的だと考えられる. しかし，貯水池操作や取水は水 需要と連動するため, 不確実性の大きな社会経済要因をシ ミュレーションに取り込む必要がある. また影響関数の作 成に必要なシミュレーションの試行も飛躍的に増えてし まう.よって本研究では陸面過程サブモデルのみを利用し た. シミュレーションに現実性を求めるなら，入念に検討 した少数のシナリオを使って, 詳細モデルを利用した水資 源シミュレーションを行えばよい．

全球気象データには陸面過程モデルの相互比較プロジ エクトである 2nd Global Soil Wetness Project (GSWP2) の提供するものを利用した 7)。これは全球を緯度経度 $1^{\circ} \times 1^{\circ}$ の空間解像度で, $1986-1995$ 年を 3 時間単位でカバ 一寸る気象データである. 短波放射, 長波放射, 気温, 比
湿, 風速, 気圧, 降雨量, 降雪量の 8 項目からなり, 入念 な精度検証が行われたものである. 本研究では平年を解析 対象とするため, 10 年平均した 3 時間データを作成し, これを現在気候のデータとみなした。

陸面過程サブモデルを利用して 1986-1995 の全球河川 流量の再現実験を行った結果，世界の主要な 37 の流量観 測地点のうち, 約 $40 \%$ の流域で年流量の誤差が $\pm 20 \%$ 以 内に, 約 $65 \%$ の流域で士 $50 \%$ 以内に収まるところが示さ れた 8). この結果は, 現在世界最高精度のデータセット9) に比べても大きな遜色がなかった. 本モデルを用いた流量 再現実験で大きな誤差が出るのは乾燥地, 半乾燥地, およ び極域の一部である.これらの地域では, 発生する流出量 が小さく, 河道や湿地からの蒸発, 取水, 凍土などの諸要 因に影響を受けやすいため, 先行研究でも流量シミュレー ションの精度が悪い地域である. しかし水資源量の大部分 を発生させる温帯, 熱帯域の流出量のシミュレーションは 妥当なので, 今回の研究への応用は可能であると判断した.

\section{（2）現在の国別水資源量の計算}

現在国別に入手可能な水資源量のデータは限られており， その中で AQUASTAT は最もよく利用されるものの一つ である. AQUASTAT は各種の統計を編集したもので, 国 別の水資源量は河川流量の観測值を元に以下のように推 定されている 10). まず,一つの河川が一つの国だけを流れ る場合は，流域内の全ての流出量をその国の水資源量とみ なしている. 左右岸の関係にある国際河川については, そ れぞれに 50\%ずつ配分されると仮定している. 上下流の 関係にある国際河川については, エジプトとスーダンの間 にあるような二力国閒の水資源量の配分が明記された条 約がある場合はそれに従い，それ以外の場合は流量の観測 值を利用し，上流から流れ込む河川流量を自国の水資源量， 下流に流れ去る河川流量を下流国のために残寸水資源量 としている. AQUASTATは, この手法が絶対的でも普遍 的でもないと認めているが, 現在入手できる情報量を考慮 した実用的な仮定だとしている. 流域ごとに水資源量を定 義することは比較的容易であるが, 流域界を無視して国境 で水資源量を配分するのは人為的な要素が大きく, たとえ 統計データと実例に基づいたとしても困難である.

AQUASTAT の手法は流量の観測值が必要なため, 本研 究のシミュレーションでは踏獎できない. 取水を含むシミ ユレーションを行う手法も考えられるが, 水需要の推定が 必要で, 社会経済面の不確実性が大きく実施が困難である. 
表-1 4 グリッドからなる仮想的な河川において $\alpha$ を変 化させたときの水資源量

\begin{tabular}{|l|r|r|r|r|}
\hline グリッド & \multicolumn{1}{l|}{ 源流 } & \multicolumn{1}{l|}{ 中上流 } & \multicolumn{1}{l|}{ 中下流 } & \multicolumn{1}{l|}{ 河口 } \\
\hline 流出量 & 1.0 & 1.0 & 1.0 & 1.0 \\
\hline$\alpha=1.0$ & 1.0 & 1.0 & 1.0 & 1.0 \\
\hline$\alpha=0.5$ & 0.5 & 0.75 & 1.0625 & 1.6875 \\
\hline$\alpha=0.0$ & 0 & 0.5 & 1.125 & 2.375 \\
\hline
\end{tabular}

表-2 流出量が極端に分布する 4 グリッドからなる仮想 的な河川において場合に $\alpha$ を変化させたときの水資源量

\begin{tabular}{|l|r|r|r|r|}
\hline グリッド & \multicolumn{1}{l|}{ 源流 } & \multicolumn{1}{l|}{ 中上流 } & \multicolumn{1}{l|}{ 中下流 } & \multicolumn{1}{l|}{ 河口 } \\
\hline 流出量 & 1.0 & 1.0 & 0.0 & 0.0 \\
\hline$\alpha=1.0$ & 1.0 & 1.0 & 0.0 & 0.0 \\
\hline$\alpha=0.5$ & 0.5 & 0.75 & 0.5625 & 0.1875 \\
\hline$\alpha=0.0$ & 0 & 0.5 & 1.125 & 0.375 \\
\hline
\end{tabular}

そこで, $1^{\circ} \times 1^{\circ}$ の空間解像度で得られた全球の流出量を, 以下のアルゴリズムに従って河川網を流下させることに より，上下流の関係を考慮しながら国別の年水資源量を推 定した。全球の河川網データには Total Runoff Integrating Pathways (TRIP)を利用した ${ }^{11}$ 。これは全球 を緯度経度 $1^{\circ} \times 1^{\circ}$ の空間解像度でカバーする河道網データ である.

アルゴリズムはTRIPを利用し，上流から下流に向けて 式(2)で算出する年水資源量 $\mathrm{W}$ を引き抜きながら年流出量 を流下させていくというものである. 各グリッドからの流 下量 Oは以下のように表される.

$$
O_{i, j}=R_{i, j}+I_{i, j}-W_{i, j}
$$

ここで $\mathrm{R}$ は計算対象グリッドの年流出量, $\mathrm{I}$ は上流からの 流下量, W は年水資源量である. 添え字の i,jはそれぞれ 緯度 $i$, 経度 $\mathrm{j}$ のグリッドのデータを示すものとする. グ リッド毎の年水資源量 Wは以下のように定義する.

$$
W_{i, j}=\alpha R_{i, j}+I_{i, j} n_{i, j} / n_{\max , i, j}
$$

ここで $\alpha$ は全球一律の倸数, $\mathrm{n}$ は源流グリッドを 1 とし河 ログリッドまで順に増えていく整数值で $\mathrm{n}_{\max }$ は河口グリ ッドでの值である.式(2)の右辺第一項は自己のグリッドで 発生する流出量による水資源量, 右辺第二項は上流加の 河川流量による水資源量である. 第二項は上流ほど下流の 水利用に配慮して取水量を制限することを仮定している.

このアルゴリズムから得られる水資源量の計算值の性 質を理解するため仮想的な流域を考えよう.4グリッドか らなる仮想的な河川があり, 源流, 中上流, 中下流, 河口
と直列につながっているとする. 式(2)の $\mathrm{n}_{\max }$ は 4 である. 各グリッドから発生する年間流出量は 1.0 とする. $\alpha$ を 0 , $0.5,1.0$ と変化させたときの各グリッドの水資源量を示し たものが表-1である. まず $\alpha$ を1.0にした場合，すなわち 自己のグリッドで発生した流出量をすべて取水してしま う場合, 各グリッドの水資源量は流出量と等しくなる. 一 般に河川は上流部が山地で人口も水利用も小さく，下流部 が平地で人口も水利用も大きいことを考慮すると，この水 資源量の配分は現実的ではない. 次に $\alpha$ を 0.0 にした場合, すなわち自己のグリッドで発生した流出量をすべて下流 に流してしまう場合, 水資源量は源流でゼロで, 下流に向 かって急激に増えていく.この自己グリッドで発生した流 出量をすべて下流のために残すという配分も現実的では ない. そこで本研究では染意的だが，この中間として $\alpha$ $=0.5$ とおいた. このとき表-1 に示すように, 上流から下 流への水資源の移転が起こり, 少なくとも $\alpha=1.0$ や $\alpha=0.0$ よりも現実的な配分となる. ここで，式(1) (2)を解くと水 資源量は $\alpha$ に関して線形なので， $\alpha=0.5$ のときの各グリ ッドの水資源量は $\alpha=1.0$ と $\alpha=0.0$ のときの中間值となる ここで表-2 のように，上下流で流出量に極端な分布が ある場合についても考えておく. 河口グリッドは流出量に そしいため, 上流からの河川流量への依存度が高いと考え られるが, このアルゴリズムでは河口に配分される水資源 量は小さい. ナイル川下流域のエジプトなどはこのケース に相当し, スーダンとの二カ国条約により人為的に割り当 てられている現実の水資源量に比べ, 本研究の推定值は著 しく小さくなってしまう.これらの特殊なケースについて の対処は今後の課題である.

最後に $2.5 \times 2.5^{\prime}$ の国境データ 12を利用して国別の年水 資源量を推定した。 もとの気象データの空間解像度が緯度 経度 $1^{\circ} \times 1^{\circ}$ と粗いため, 島嶼国などでは国土面積が過小評 価されてしまう傾向が見られた. そこで実際の国十面積の データを利用し，面積による国別水資源量の補正を行った。

本研究では地下水を直接扱っていないが, 世界全体では 全取水量の $15 \%$, 約 $600-700 \mathrm{~km}^{3} / \mathrm{yr}$ を地下水から取水し ていると推定されている ${ }^{13}$. ただし，この統計の地下水 は浅層で河川水との交換性が高いものと, 深層で再生性の 低いものを含んでいる.このうち, 浅層の地下水に関して は, 本研究における流出量が降水から蒸発を除いた残差と して算出されているため, 間接的に流出量に含まれている とみなすことができる. 深層の地下水はモデルて扱えない が，これは枯渴が心配される持続可能性が低い水資源であ り, 本研究の対象とする長期の水資源量評価からは除外し てもよいと判断した. 


\section{（3）現在の国別水資源量の検証}

得られた国別水資源量を世界の水資源に関する統計デー 夕 AQUASTAT ${ }^{10,14)}$ と比較した結果を図-1に示寸. 水資源 量の上位 50 ヶ国（年間水資源量 $130 \mathrm{~km}^{3} / \mathrm{yr}$ 以上の諸国） についての誤差は概ね土40\%以内に収まることが示され た. 2 （1）で示した現時点の流量シミュレーションの精 度を考慮すると, モデルが現在の水文過程と国別水資源量 を概ね再現できることが示された：また， $\alpha$ の設定による 推定精度への感度は, 少なくとも年閒の水資源量が $130 \mathrm{~km}^{3} / \mathrm{yr}$ を超える主要国に関しては小さいことが示さ れた. ただし，本研究の水資源量は AQUASTAT よりも 小さくなる傾向がある．全球の総水資源量の推定值は $36,000 \mathrm{~km}^{3} / \mathrm{yr}$ から 44,000km³/yr までのばらつきがある 9). 本研究は若干小さめの $39,000 \mathrm{~km}^{3} / \mathrm{yr}$ であるのに対し, AQUASTAT は大きめの $44,000 \mathrm{~km}^{3 / 1} \mathrm{yr}$ である. しかし， AQUASTAT 以外に世界の全ての国を対象にした信頼性 の高い水資源の統計データがないこと, 観測河川流量をべ 一スにした先行研究間を比較しても数干 $\mathrm{km}^{3} / \mathrm{yr}$ 程度のば らつきが発生していることから, 本研究の過小評価傾向は 許容範囲にあるとみなした，ただし，最近の研究では $40,000 \mathrm{~km}^{3 / y r}$ を下回る推計結果が出されることが多いこ とを考慮すると 8), AQUASTAT は若干過大と言えるかも しれない. 40\%以上過小評価された諸国にはペルー,チリ， エクアドル, ネパールなど山岳地域が多く含まれるが, こ れらの地域では降水の地形効果を考慮することなどによ り，今後改善が期待できると考えられる 15)。 また 40\%以 上の誤差を出した国の中にヨーロッパ諸国が 2 力国含ま れるが, GSWP2 の降水データがヨーロッパの中高緯度で 降水量を過大評価する傾向に起因しているかもしれない．

\section{（4）将来の国別水資源量の計算}

次に詳細モデルを利用して温暖化時の国別の水資源量を 推定した. まず計算対象としたのは温暖化が最も進展する 21 世紀末の 2090 年付近である. 利用した気候シナリオは 国立環境研究所・東京大学気候システム研究センター・地 球環境つロンティア研究センター引開発した大気海洋結 合モデルMIROC3.2高解像度版にSRESA1B排出シナリ オを与えた結果である.この気候シナリオを選定した理由 は空間解像度が緯度経度約 $1.125^{\circ} \times 1.125^{\circ}$ と詳細で, GSWP2 と同じ項目についてデータを入手可能であった からである. この気候シナリオは 2001-2100 年の 100 年 をカバーするが, 20 世紀を再現した 1900-2000 年の計算 結果も入手した.

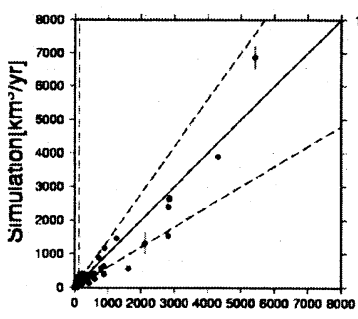

AQUASTAT $\left[\mathrm{km}^{3} / \mathrm{yr}\right]$

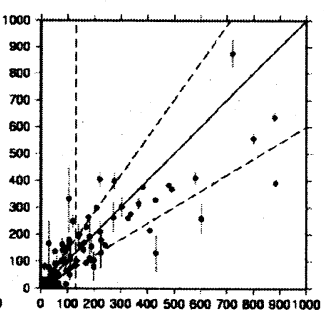

AQUASTAT[ $\left.\mathrm{km}^{3} / \mathrm{yr}\right]$
図-1 AQUASTAT (横軸) と詳細モデル (綐軸)による国別水 資源量の比較. 右図は左図の一部拡大. 破袙は土 $40 \%$ の誤差範囲 を示す．鉛直の破線より右のプロットは国別の水資源量上位 50 ヶ国を示している. エラーバーは式(2)において， $\alpha$ を 0 から 1 ま で変化させた場合の軌跡を示す。

これらを利用し, 将来の 3 時間単位の気温および降水シ ナリオを作成した. まずデータを緯度経度 $10 \times$ × 1 ○に変換し, 気温と降水について 1986-95 年の 10 年平均 (GCM の現 在気候) と 2086-2095 年の 10 年平均 (GCM の将来気候) の月平均データを作成した. 将来の 3 時閒デー夕は, 気温 に関しては GSWP2 の現在気候に GCM の将来気候と現 在気候の偏差を月単位で加えた。降水に関しては同じく両 者の変化率を月単位で掛けた: この将来気候值の作成の仕 方は先行研究でもよく利用されている4).

$T_{2086-95, m, d, h}=T_{1986-95, m, d, h}^{G S W P 2}+\left(T_{2086-95, m}^{G C M}-T_{1986-95, m}^{G C M}\right)(3)$

$P_{2086-95, m, d, h}=P_{1986-95, m, d, h}^{G S W P 2} \times \min \left(\frac{P_{2086-95, m}^{G C M}}{P_{1986-95, m}^{G C M}}, 3.0\right)(4)$

ただし, $T_{1986-95, m, d, h}^{G S W 2}, P_{1986-95, m, d, h}^{G S W P 2}$ はそれぞれ GSWP2

による 1986-95 年平均の 3 時間単位の気温と降水を示寸. 右肩の添え字 GCM は MIROC の結果であることを，右 裾の添え字 2086-95 は2086-95 年平均であることを示す. 温暖化により, 日周期や日々変動も変化すると考えられる が, 本研究では季節変動性 (月単位) の変化のみを対象と した. これ以外の気象要素の值は, 将来も GSWP2 の現 在気候と変わらないと仮定した. 得られた流出量を利用し， 国別水資源量を計算した.

\section{3. 水資源影響関数を利用した国別水資源量}

\section{（1）影響関数の作成}

詳細モデルを利用し, 入力気象データを次のように変化さ せてシミュレーションを行い，影響関数を作成した. まず 現在の 3 時間単位の気象データについて, 気温を全球・通 
年一律に $-5{ }^{\circ} \mathrm{C}$ から $15^{\circ} \mathrm{C}$ まで $1^{\circ} \mathrm{C}$ 刻みで 21 通りに，降水を 同じく-75\%から+200\%まで 12 通り変化させることによ り, 合わせて 252 通りの気象データを作成した. つまり, 式(3)と(4)の右辺第二項を月単位·GCM の空間分布ではな く, 年単位・全球一律に変化させたと言える. このとき気 温と降水データ以外の短波放射, 長波放射, 比湿, 風速, 気圧のデータは現在の 3 時間データ (GSWP2 の值)を利 用した. 得られた流出量データを利用し，国別の水資源量 を計算し, データベースとして保存した.

AIM/Impact[Policy]がこのデータベースを活用する仕 組みは以下の通りである. まずユーザ操作により全球平均 気温と GCM（気候と降水の変化の空間的分布パターン） が決定されると, 国別の気温偏差と降水変化率が計算され る. 作成されたデータベースの中から気温变化と降水変化 の組み合わせが最も近い 4 うテデータの幾何平均を取る ことにより，国別の水資源量が得られる.

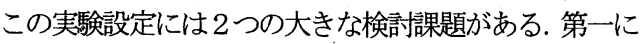
気温と降水の上下限と刻み幅の妥当性である. 第二にこう して影響関数から得られた結果と詳細モデルのそれが一 致するかどうかである. それぞれについて検討する.

\section{（2）気温と降水の上下限と刻み幅の設定}

気温と降水の上下限の設定の妥当性を検討するため, 将来 の気候シナリオで, 気温と降水が現在值に比べてどれくら い変化するのかを解析した. 解析対象としたのは, 気候変 化が最大になる SRES A2 シナリオ16)の 2081-90 年, およ び最小になる SRES B1 シナリオ 16)の 2001-10 年である. IPCC の第 4 次評価報告書に A2 気候シナリオを提供した 18 の GCM（B1 は 20）について，世界の 251 の国の気 温偏差および降水変化率を求め図示したのが図-2である. 現在気候としては $1981-90$ 年の 10 年平均を利用した.

全データの気温偏差は- $3.75^{\circ} \mathrm{C}$ から $+15.0^{\circ} \mathrm{C}$ まで, 降水量 変化率は-99.9\%から+7425\%までであった. ただし降水量 が+200\%以上になるのは全 91580 ケース中わずか 132 ケ 一スしかなく，無視できると考えた. よって，気温は $55^{\circ} \mathrm{C}$ から+15 $\mathrm{C}$ まで，降水量は-100\%から+200\%まで変化させ れば, AIM/Impact[Policy]が参照する 2001 年から 2100 年までのほぼ全ての気象条件を網羅するデータベースが 構築できることが示された. ただし気温が $8{ }^{\circ} \mathrm{C}$ より上昇す るものは 97 ケース (全体の 0.1\%) しかなく, 仮にこれら を無視すれば，全体の計算量を $35 \%$ 削減できることが分 かったが, 気温が現在值と大きく乘離した際の影響関数の

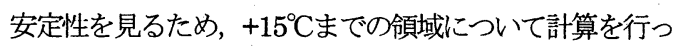
た.

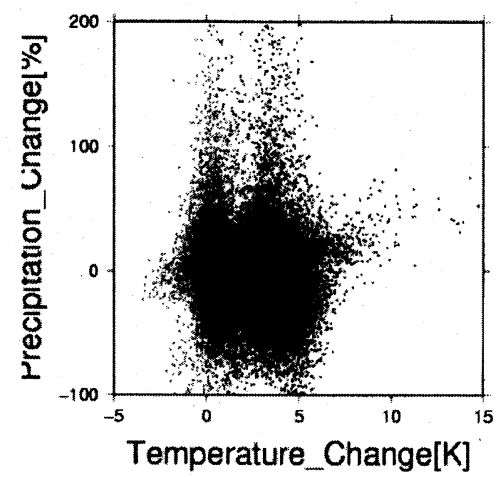

図-2 年平均気温の偏差および年平均降水量の変化率を国別・念 別にプロットしたもの. グレー : SRES B1 シナリオにおける 2001-2010年の 20 の GCM の予測值, 黒：SRESA2 シナリオ における 2081-90 年の 18 のCM の予測值
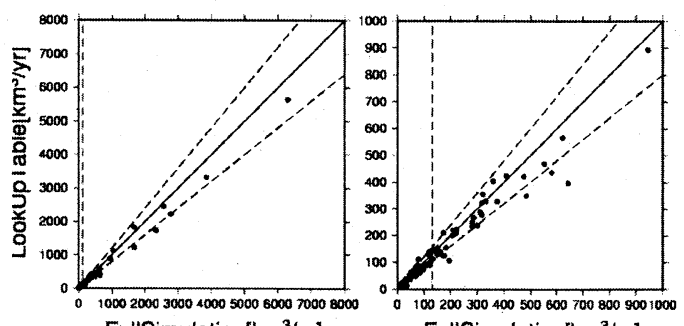

FullSimulation[ $\left.\mathrm{km}^{3} / \mathrm{yr}\right]$

FullSimulation $\left[\mathrm{km}^{3} / \mathrm{yr}\right]$

図-3 詳細モデル (横軸) と影響関数 (縦軸) による国別水資源 量の比較. 右図は左図の一部拡大. 破線は $\pm 20 \%$ の誤差範井を示 す.鉛直の破線より右が水資源量上位50 ケ国のプロットである.

\section{（3）影響関数の検証}

次に影響関数が詳細モデルの代替となりうるか否かを検 討する. 検討対象とするのはAIM/Impact[Policy]で GCM にMIROC を, 解析期間に 2086-95 年の平均を, 気温偏 差と降水変化率を計算する際の現在気候に 1986-95 年の 平均をとった場合である. 詳細モデルを利用した 2086-95 年の国別の水資源量を横軸に, 影響関数を利用したものを 縌軸に取り,プロットしたものが図-3である.

プロットは概ね土 $20 \%$ の範用範囲内に収まり, 影響関数 は詳細モデルの代替になることが示された. ただし影響関 数から得られた水資源量は詳細モデルのそれに比べて若 干過小になる傾向が見られる. 水資源量上位 50 ケ国で $20 \%$ 以上の過大評価となったのはボリビアの 1 国のみで, $20 \%$ 以下過小評価となったのはアメリカやインド, マダ ガスカル，モザンビーク，ベネズエラなど 9 ケ国ある. 

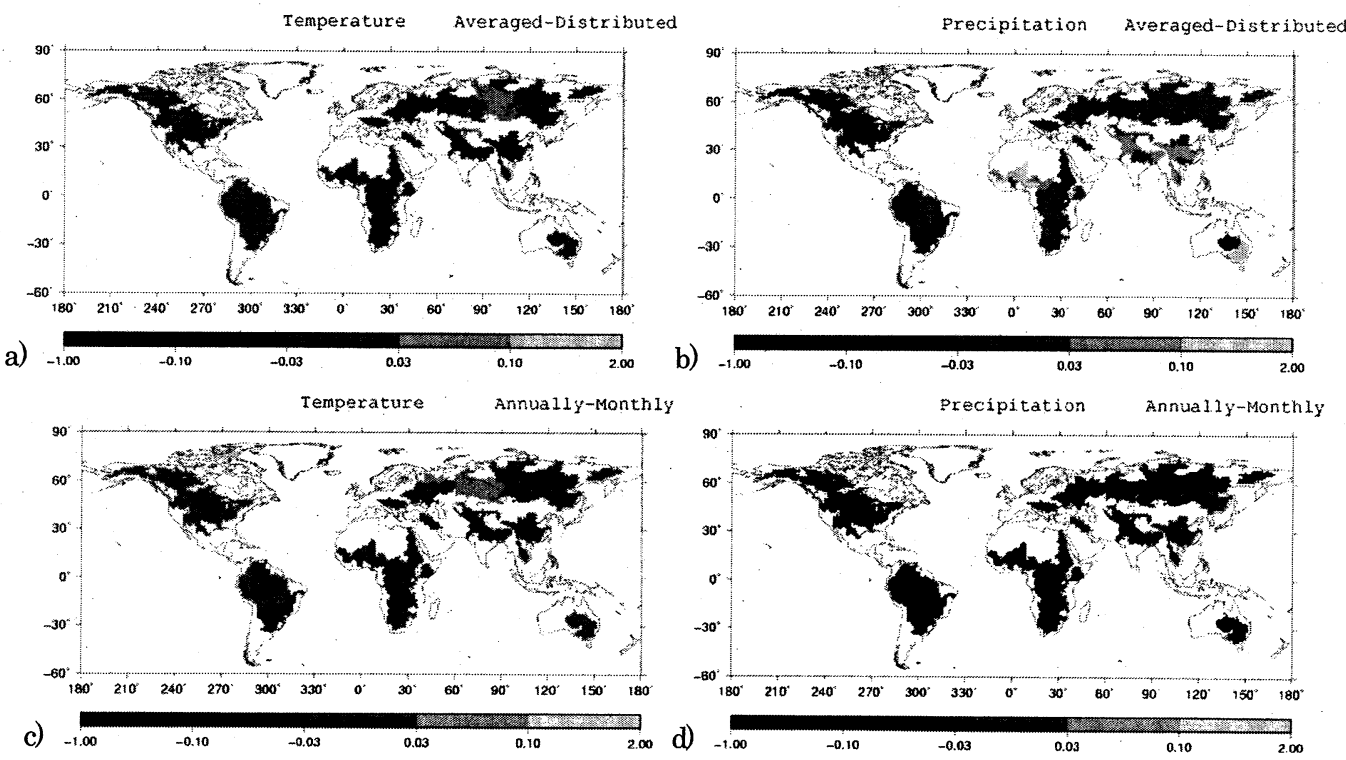

図-4 a)気温をグリッド単位で変化させた場合と流域単位で変化させた場合の流出量の偏差を正規化したもの. b)降水を グリッド単位で変化させた場合と流域単位で変化させた場合の偏差. c)気温を月単位で変化させた場合と年単位で変化さ せた場合の偏差.d)降水を月単位で変化させた場合と年単位で変化させた場合の偏差.

\section{（4）国単位および年単位で変化させた影響}

影響関数から得られる水資源量がなせ詳細モデルよりも 過小になるのかについて原因を考察しておく. 詳細モデル と影響関数の違いはいくつかあるが, 前者が気温偏差と降 水変化率を月単位・グリッド単位で変化させているのに対 し, 後者は年単位・国単位で変化させていることが最も大 きいと考えられた.

そこで，まず気温と降水を国単位で変化させた影響につ いて考察する. 国際河川における水資源の配分の不確実性 を除去するため，世界の流域面積上位 50 河川の流域別の 解析で代替寸ることにする。気温について流域単位で変化 させた場合とグリッド単位で変化させた場合の流出量の 偏差を取り，正規化して示したものが図-4a，同じく降水 について示したものが図-4bである. 結果は河口での流量 の偏差について示している. まず気温については土 $3 \%$ 以 上の変化が現れた流域は 3 しかなく, 感度が比較的小さい ことが示された. 次に降水であるが， $\pm 3 \%$ 以上の差異を 持つ流域が 18 あることが示された，ただし，過大評価と 過小評価はそれぞれ 9 流域ずつで, 流出量の差異も 2 流域 を除き, $\pm 10 \%$ 末満である. よって影響関数の過小評価の 主な原因ではないことが示された。

次に気温と降水を年単位で変化させた影響について考 察する. 気温について年単位で変化させた場合と月単位で
変化させた場合の流出量の偏差を取り, 正規化して示した ものが図-4c，同じく降水について示したものが図-4d で ある. まず気温を変化させた場合であるが, 年単位で変化 させた場合と月単位で変化させた場合で, $\pm 3 \%$ 以上年流 出量に差が現れたのは 6 流域であった. 次に降水を変化さ せた場合であるが，気温に比べて差が大きく， $\pm 10 \%$ 以上 の顕著な差違が現れた流域が北米, 南米, アフリカ南部, シベリア, 中央アジアからインド覀大陸北部など 15 流域 も示された. これらの地域の全てで, 年単位で変化させた 流出量は月単位で計算されたものに比べて過小となり, 前 項で示された $20 \%$ 以上過小評価された諸国の多くはこれ らの地域にあることが確認された. よって, 影響関数から 得られる国別水資源量が詳細モデルに比べて過小になる 主な原因は降水変化の季節変化性を無視したことにある と考えられる.この結果は降水変化に対する全球水文モデ ルの感度が高いことを示しており, 影響関数作成時に降水 を月別に変化させる必要性を示唆している. しかし，変化 率を $25 \%$ 刻みで $75 \%$ から+200\%まで 12 通り，月単位で 変化させた場合, 1212 回のシミュレーションが必要となり, 計算機負荷の観点から実施可能かどうか今後検討する必 要がある，したがって，月別変化を取り込むには，今後更 なる検討が必要となる. 


\section{4. グローバル水資源影響関数の考察}

前節で得られた水資源影響関数の例として日本に関する 結果を図-5 に示す. 気温の上昇（横軸の右向き）ととも に水資源量が減少していき(色が濃くなり), 降水の減少 （縦軸下向き）とともに水資源量が減少していく（色が濃 くなる）ことが分かる. 気温の上昇に対する水資源量の減 少率と降水の減少による水資源量の減少率の関係は国毎 に異なる. 気温が現在值に対して $3^{\circ} \mathrm{C}$ 上昇した場合と降水 量が $25 \%$ 減少した場合でそれぞれ国の水資源量がどれく らい減少するかを示したものが図-6である.参考として, 日本，インド，中国，ロシアをそれぞれ J, I, C, R として プロットした. 気温に対する感度はインド, 中国, ロシア の順に, 降水に対する感度はロシア, インド, 中国の順に 高くなる. 以下に簡単にこの関係を説明しておく. ロシア の主な水資源量は冬期の降雪に由来するが, 降雪が積雪と して春まで維持されて，一気に融け出した場合，蒸発によ る損失が小さく，降水量の減少 $(25 \%)$ と水資源量の減少 (37\%)の乘離が小さい, しかし, 気温が上昇し, 積雪の融 解がおきると, 冬期にも蒸発による損失が発生し, 急速に 水資源量が減少する.インドの主な水資源量恃雨期の降水 であるが, 雨期には流出が蒸発に卓越し, 蒸発による損失 が比較的小さい.これに対して中国では蒸発が流出に年間 を通じて卓越し，蒸発の損失が大きい.

\section{5. 結論と今後の課題}

本論文では温暖化政策支援モデル AIM/Impact[Policy]に 搭載するためのグローバル水資源影響関数の作成を行っ た. まず詳細な全球水文モデルを利用したシミュレーショ ンを実施し，その結果が現在の国別水資源量を概䄪 $\pm 40 \%$ の誤差範囲内で再現できることを確認した. 次に詳細なモ デルを利用したシミュレーションを行い, 影響関数を作成 した. 影響関数から得られる国別の水資源量と詳細モデル から得られるそれとが士 $20 \%$ の誤差範囲内で一致するこ とを確認し, 影響関数から詳細モデルと同等の結果が再現 されることを示した. ただし, アメリカや中国などでは詳 細モデルによる結果と影響関数による結果に乘離が見ら れた. これは影響関数作成時に将来の降水デ一夕を年一律 に変化させたことが原因だと考えられ，今後の検討が必要 であることが示された. また, 本論文では 2086-95 年の期 閒を中心に影響関数の妥当性の検証を行ったが, それ以外 の期間についても検討する必要がある.

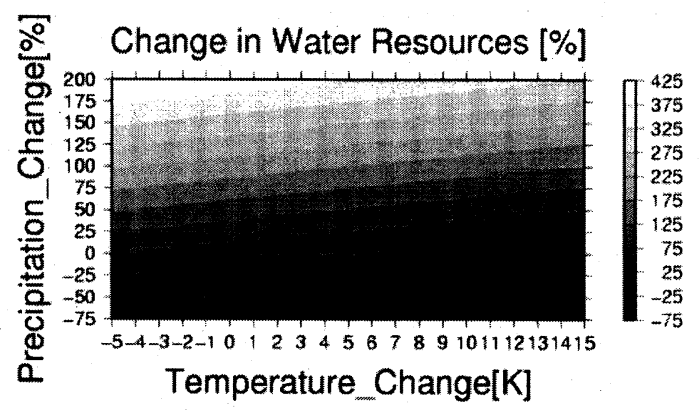

図-5 日本の年間水資源量の気温変化と降水変化に対寸 る感度. 気温を $-5^{\circ} \mathrm{C}$ から $+15^{\circ} \mathrm{C}$ まて変化させた場合 (横軸)， 降水量を- $75 \%$ から $200 \%$ ま変化させた場合 (縦軸) の水 資源量の変化を示す。

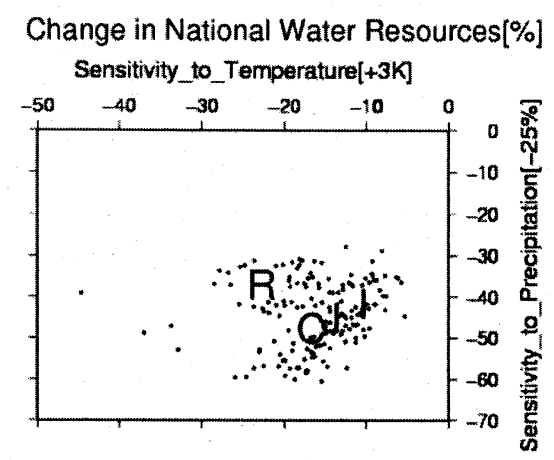

図-6 国別の水資源量の感度. 気温を $+3{ }^{\circ} \mathrm{C}$, 降水 $-25 \%$ の変 化させた場合の水資源量の変化割合を示寸。

影響関数が AIM/Impact[Policy]に実装されることによ り, 依然として政策検討の現場に対して科学的推計の詳細 な手順や背景を逐一示すことは困難であるが, 温暖化影響 の評価結果をより透明性を持って示すことが可能になる. また，これまで分野別に行われてきた温暖化影響評価が AIM/Impact[Policy]に集約されることで, 分野間の影響の 相互比較ができるようになると期待される. さらに, 長期 的な気候安定化目標とそれに至る道筋を, 温暖化の定量的 影響を考慮しながら検討することが可能になる.

ただし，影響関数による評価には限界もある，例えば AIM/Impact[Policy]は国単位で計算を行うため, 国内分布 を示すことができない，例えば中国では南北で，アメリカ では東西て水資源量が大きく異なるため, 詳細な検討には 国内の地域分割が必要である。 また, 本研究では年河川流 量を水資源と見なしたが, 流量の季節変動や年々変動, ダ ムなどのインフラの有無も重要な要素である: こうした詳 細な検討を行う分野別の影響評価をどのように影響関数 に組み込んでいくかについて後検討する必要がある. 
謝辞 : 本研究は地球環境研究総合推進費 S-4「温暖化の危 険な水準及び温室効果ガス安定化レベル検討のための温 暖化影響の総合的評価に関する研究」(代表 : 三村信男) および同 B-52「アジア太平洋統合評価モデルによる地球 温暖化の緩和・適応政策の評価に関する研究」（代表 : 甲 斐沼美紀子）の成果の一部である.

\section{参考文献}

1) Hijioka, Y., Masui, T., Takahashi, K, Matsuoka, Y. and Harasawa, H, Development of a support tool for greenhouse gas emissions control policy to help mitigate the impact of global warming. Environmental Economics and Policy Studies, Vol. 7, No. 3, pp. 331-345, 2006

2) 肱岡靖明, 高橋潔, 久保田泉: 統合評価モデルを用いた温室効 果ガス安定化濃度目標下におけるイネ・小麦の潜在生産変化の 国別影響評価，環境情報科学論文集，Vol.20，pp. 19-24，2006

3) Oki, T. and S. Kanae, Global hydrological cycles and world water resources, Science, Vol. 313, No. 5790, pp. 1068-1072, 2006

4) Alcamo, J., M. Flörke and M. Märker. Future long-term changes in global water resources driven by socio-economic and climatic changes, Hydrological Sciences-Journal, Vol. 52, No. 2, pp. 247-275, 2007

5) 花崎直太, 鼎信次郎, 沖大幹 : Bucket 型の陸面過程モデルをべ 一スにした全球統合水資源モデルの開発，水工学論文集，Vol. 50, pp. 529-534, 2006

6) Manabe, S., Climate and the ocean circulation 1. The atmospheric circulation and the hydrology of the earth's surface. Mon. Wea. Rev., Vol. 97, No. 11, pp. 739-774, 1969

7) P. A. Dirmeyer, X. Gao, M. Zhao, T. Oki and N. Hanasaki, The second global soil wetness project (GSWP-2), Bulletin of American Meteorological Society, Vol. 87, No. 10, pp. 1381-1397, 2006.
8) Hanasaki, N., S. Kanae, T. Oki, K. Masuda, K. Motoya, Y. Shen and K. Tanaka, An integrated model for assessment of global water resources. Part 1: Input meteorological forcing and natural hydrological cycle modules, to be submitted to the Hydrology and Earth System Sciences (ftp//hydro.iis.u-tokyo.ac.jp/pub/hanasakitemporary/HESS2007Part1_6.doc)

9) Döll, P., F. Kaspar, and B. Lehner, A global hydrological model for deriving water availability indicators: model tuning and validation, Joumal of Hydrology 270, 105-134, 2003.

10) FAO, Review of world water resources by country, Water Reports, 23 , FAO, 2003

11) T. Oki and Y. C. Sud, Design of Total Runoff Integrating Pathways (TRIP)A global river channel network, Earth Interactions, Vol2, 1998

12)Center for International Earth Science Information Network (CIESIN), Columbia University; and Centro Internacional de Agricultura Tropical (CIAT). Gridded Population of the World Version 3 (GPWv3): Population Grids. Palisades, NY: Socioeconomic Data and Applications Center (SEDAC), Columbia University. 2005. Available at http://sedac.ciesin.columbia.edu/gpw. (downloaded on 28/Feb/07).

13）松岡譲，高橋絜 : 地球水資源問題の現状と今後, 地球水資源 の管理技術，森澤畺輔編，コロナ社，ppl 44,2003

14) FAO, AQUASTAT, 2004 (http://www.fao.org/ag/aglaglw/aquastat/main/index.stm)

15) Adam, J.C., E.A. Clark, D.P. Lettenmaier and E.F. Wood, Correction of Global Precipitation Products for Orographic Effects, J. Clim., Vol 19, No. 1, pp. 15-38. , 2006

16) Nakicenovic, N. and Swart, R, Special Report on Emissions Scenarios: A Special Report of Working Group III of the Intergovernmental Panel on Climate Change. Cambridge, Cambridge University Press, 2000

\title{
DEVELOPMENT OF A GLOBAL WATER RESOURCES SCHEME FOR CLIMATE CHANGE POLICY SUPPORT MODELS
}

\author{
Naota HANASAKI, Yuji MASUTOMI, Kiyoshi TAKAHASHI, \\ Yasuaki HIJIOKA, Hideo HARASAWA and Yuzuru MATSUOKA
}

\begin{abstract}
A scheme was developed to estimate the change in national water resources under climate change. Using a distributed global hydrological model, 252 sets of simulation were conducted shifting temperature from -5 to +15 degree Celsius, and precipitation from $-75 \%$ to $+200 \%$ from current climate, and a database of national water resources under climate change was developed. The scheme requires little computational resources, because it just needs to refer the database. Therefore, it is suited to couple with climate change policy support models in which climate condition varies quite frequently. The output of this scheme agrees well with that of the original detailed model with an uncertainty of $\pm 20 \%$.
\end{abstract}

